\title{
Albanian Railway in the Framework of European Integration: An Overview and Development Opportunities in the Future
}

\author{
Fabjola Bramo \\ PhD candidate \\ Ministry of Interior of the Republic of Albania, Tirana, Albania \\ Email: fabjolabramo@yahoo.com, Mobile: +355 694109159
}

Shyqyri Llaci, Prof. Dr.

University of Tirana, Faculty of Economy, Tirana, Albania Email: shllaci01@yahoo.com, Mobile: +355672066969

Doi:10.5901/ajis.2013.v2n9p511

\begin{abstract}
Albania is a country that aspires to gain candidate status and after that the membership in the European Union. Our country has signed Stabilization and Association Agreement with the EU in 2006. From the signing of this agreement derive standards and obligations to be fulfilled, in order to be at the same level or close to the countries that are EU members. Reconstruction of the railway and standardization of their European levels is one of the most important tasks. To this day, in this sector is made little progress that hinders economic development in the country. Member states have already implemented the four guidelines for railways, while in Albania; this kind of transportation is neglected. In this paper we will discuss issues related to the problems that Albania railway system is currently facing, efforts made to their Europeanization and development opportunities in the future.
\end{abstract}

Keywords: EU standards, guidelines for railways, economic development, barriers to development

\section{Introduction}

Albania's economy is evolving. The geographical position of our country is very favorable for the development of commercial activities between states. Almost all domestic economy is already entered in the wake of capitalism. Even the few state-owned enterprises that existed until a few years ago are almost entirely privatized. Others have been granted to concession over the last 8 years. Following the signing of the Stabilization and Association Agreement with the EU, Albanian state has taken steps to eliminate monopolies and trusts in the economy. As a result of these continuous efforts, most of the local markets have been deregulated. Markets started to open up in 1992, peaking in 2000 when Albania became a member in the World Trade Organization.

Currently, Albania has the lowest rate of imports in the region. In recent years our country has signed different regional agreements to deregulate markets. Most important among them are: CEFTA and the free trade agreement with the EU. Based on these agreements, Albania has the right to export goods without tariffs or low tariffs towards the EU. In the wake of these agreements, Albania is an important partner in EU exports with almost $77 \%$ of products and $62 \%$ of imports.

The Albanian government decided that all public enterprises would be privatized in 2010. This initiative was criticized because during the global crisis period, the costs would be much lower than in normal periods. Albanian Railways is one of the public enterprises which remain in the ownership and management of the Albanian state. It is the only one which doesn't serve the economic development of the country, due to the wide problematic it bears. The network rail transport in Albania is currently very backward. Although our country is bound by the obligations deriving from the signing of the SAA, no progress has been made in this direction. Of the four EU directives on liberalization and restructuring of the railways, none has been implemented yet in Albania.

There are few related studies in the Albanian language. Given that railway infrastructure has been almost abandoned, the focus of academic research has not affected this field. Thus, in order to conduct the study, there were used studies related to the field of railway infrastructure. There is a noticeable lack of materials for the conduct of studies 
which have been undertaken by the state government or NGOs. As a result of the attention paid to the improvement and construction of road infrastructure, there has been a lack of attention to the railways.

The main purpose of this study is to establish a broad overview of the railway system in the country, to identify strengths, weaknesses, opportunities and threats. It is also intended to identify the steps to be taken or the ones unimplemented in the framework of the European directives and standards regarding railway infrastructure in Albania. The contribution of this study consists in the fact that it will serve as a basis for future studies that will be conducted regarding the implementation of EU directives in Albanian railways.

The hypotheses of this study are:

- Have the EU directives on railways been implemented in Albania and what are the related barriers?

- Identification of the opportunities and barriers to the development of such transportation in our country.

These hypotheses were raised, in order to create a clear picture of the situation of the railways in our country.

\subsection{Research methods}

This study is a qualitative research. It employs the evolution and characteristics of railway system in Albania. The purpose is to find out how railway in Albania can provide an economic development. The case study was written based on literature, official data from Albanian railways, and round tables with experts of the field, economy, sociology, business etc. All these sources and discussions gave us information to prepare this paper. We must point out that the lack of the official information about the railway in Albania.

\section{Railway deregulation in Europe}

Over the last decade the railway industry has suffered negative effects of globalization and unexpected changes due to the development of various businesses. These effects are in fact associated with the fragmented nature of such transport in Europe as well as the fact that the railways have been for a long period of time part of very low income and budgeting. The European Union has initiated and approved three strategic packages of directives in order to recover and meet the needs of this important sector of transport. The 3 most developed European countries regarding rail networks are Germany, Great Britain and Sweden (Simola \& Szekely 2011).

The failure of market liberalization in Europe has a variety of reasons, and we can mostly mention fragmented licensing scheme, the lack of interaction of regional railway with the international one, the lack of licensed rail drivers by the EU, transportation means, and allocation of security systems. (Di Pietrantonio \& Pelkmans 2004).

Railway transportation brings social advantages in different aspects. We can mention the fact that if a person is employed or not, it can directly affects his perception on the benefits offered by the railways. This transport serves him to go to the workplace. If someone is involved in a group or political activity, it is also important. This benefit is also followed by the fact that there is no requirement for the passengers to be subjects of entry control recording, etc., as there is required in air transportation. Social support is another advantage; it consists in the fact that railway costs provided, favors individuals in reaching different locations, meeting their needs by being close to family members, friends and neighbors. Last but not least is participation. This mode of transport enables users to pursue their hobbies, participation in various events, organizing activities, etc. We should emphasize that the key social benefit it offers is mobility. Lack of such aspect, would cause barriers of transportation to workplaces, difficulties in organizing trips for pleasure, education, health needs, shopping, participation in social and artistic events. Thus, mobility is what enables individuals to engage in social life.(Deloitte 2011)

Other advantage associated with rail can bring the fact that trains can be loaded with higher weights in comparison with weights the road vehicles can carry. (Which is its main competitor)? Number of people, goods being transported on a train is several times higher than what road vehicles can carry. In this case, we also note the increasing efficiency of Railway Transport. This benefit brings as a result lower ticket prices or travel costs, thus other consequential benefits derive. (Deloitte 2011).In the recent years it has been noted much governmental efforts aiming to promote the development of this sector in order to increase efficiency, reduce deficits and improve quality of service (Gomez-Ibanez 2004).

In developed countries, heavy transportation means for freight are forced to pay higher prices for damages caused to roads by heavy vehicles. Besides fuel costs, heavy vehicle tax increases the cost of transported goods. This brings disadvantages to road transport in comparison with rail (Deloitte 2011). Efficiency of a market depends on the relationship between the operating company, infrastructure and governmental agencies. But this activity process works differently 
from country to country. On the other hand, the price pressure is still strong in the rail market for various reasons. Reasons can include consumer trends, focusing on the fact that consumers demand more and pay less for services offered (Simola \& Szekely 2011).

The following table will demonstrate an overview of the methods of competitiveness and market structure (adapted from e Laisi 2009 which has adapted table from Baye 2005 \& Begg 1994: 157)

\begin{tabular}{|l|c|c|c|c|}
\hline \multicolumn{1}{|c|}{ Features } & $\begin{array}{c}\text { Optimal } \\
\text { Competitivenness }\end{array}$ & $\begin{array}{c}\text { Monopolistic } \\
\text { comp. }\end{array}$ & Oligopoly & Monopoly \\
\hline No. of companies & several & Several & Little & One \\
\hline Ability to cost competitivenness & None & Limited & Several & Considerable \\
\hline Barriers to access & None & None & Several & Entire \\
\hline Product & Homogene & Differentiated & Hom. And diff. & Exclusive \\
\hline Example & Agriculture & Fast-food & Vehicles & Postal offices \\
\hline
\end{tabular}

\section{Benefits of Railway}

In 1991, discussions began on the idea of liberalization of the railway market in Europe. According to Directive 91/440/EC, the railway transport in Europe would be part of the open competition. This would be achieved through market access of different operators. The railway would not be a monopoly of the state or a single or two companies. Despite the announcement of this Directive, it took 10 years to the implementation of other steps, which were linked to 3 next related directives. The implementation of these directives intended to increase the rate of importance and value of rail transports in Europe, making it competitive by bringing the access of different operators. Rail transport is considered more eco-friendly, and it also offers lower fees than other ways.

\subsection{Four packages for railways in EU}

There were 4 packages provided for the railways in the EU countries:

1. The first package was adopted in 2001. It consists of 3 directives, concerning the improvement of competitiveness in the related industry, international cargo transportation as well as infrastructure capacity utilization. Under this package, the financial sector suggested separation of transport of passengers, goods, and creating management of a self-financing structure.

2. The second package was adopted in 2004 and consists of directives related to railway transportation security conditions in Europe. Under this package, after January 2007, the international railway transport of goods would be set by the legal framework of the European Railway Agency.

3. The third package was adopted in 2007. It consists of guidelines suggesting liberalization of international passenger transport in Europe in 2010.

4. The fourth package was adopted in 2010.

When discussing the benefits of railways, deregulated markets and models to be adopted in order to recover this type of industry, we should strongly take into this sector's long history. In 1949, several states created the Council of Europe, followed by the Common Market enabling commercial exchanges of goods and individuals among member states. This important initiative dated in 1957 was followed by a single market in 1993 called "four freedoms" (History of the EU 2008) for freight, movement of individuals, services and money (EU 2009). Free movement of goods was followed by the need for transportation in the countries of the European Union. The next initiative was Directive 91/440, whereby the railways operational structure should be separated from infrastructure management (Di Pietrantonio \& Pelkmans 2004, the European Union 2009).

\subsection{Carte Blanche}

This Directive was followed by the Carte Blanche in 1992, which brought the idea of deregulation of transport market ${ }^{1}$. It was followed by a second Carte Blanche entitled "Strategy for the revitalization of the railway community", which came out in 1996. According to this strategy, it was believed that the railways would play an important role in economic 
development in the future of Europe. In addition, road traffic would be partly transferred to the railways, considering that roads would be less problematic (Di Pietrantonio \& Pelkmans 2004: Makitalo 2007: Laisi 2009: European Union 2009). In 2001, a new Carte Blanche was approved by the European Commission called "European Transport Policy for 2010: time to decide". In this paper was emphasized the idea of rail transport development and the creation of a balance between road transport. The goal was the revival of the industry, but what made it most important was the effort to push EU member states to support their transport system in terms of social, economic and environmental prospective. (Makitalo 2007: European Union 2009: Summary of Carte Blanche 2001).

\section{Albania and Europeanization of Railway}

Albanian Railways is a state monopoly. It bears the status of joint company and is supervised by the Ministry of Transport and Public Works. This company has full rights on all sectors of railway, such as possession of railway infrastructure and operations, finance, human resource management etc. AR operates in the market as a single (exclusive) company without the existence of other competitors. Its role was provided by the Railway Code, which was approved by the parliament. Every year AR issues a balance statement, ranging a debit amount of 2.1 million dollars $(20,052,009)$. It is quite unlikely to recover operational costs.

The Albanian government decided that all public enterprises privatized in 2010. This initiative was criticized because of the global crisis period prices are several times lower than in normal periods. Albanian Railways is one of public enterprises remains in the ownership and management of the Albanian state. It is not only serves the economic development of the country, since it carries wide problem. Network Rail transport in Albania is currently very backward. Although our country is bound by the obligations deriving from the signing of the SAA, no progress has been made in this direction. Of the four EU directives on liberalization and restructuring of the railways, none has been implemented in Albania.

\subsection{The role of government}

Due to the favorable geographical position, low cost of using this transport, the fact that it is a developing country and that adheres to gain full EU candidate status, the Albanian government should encourage public and private initiatives for rail development. Public-private initiatives will expedite the process of reconstruction and modernization of its railway network. It is easier that reconstruction to be done by private operators than from public funds, taking into consideration that the most important are freight transport. The support of governing bodies consists on policies drafting for partial or full privatization this sector. Countries that have applied rail liberalization appear to have succeeded. Liberalization would encourage the entry of new technologies conform to European standards and beyond, and will encourage a healthy and fair competition between private operators. In this way, it would become possible the rapid development of this sector and reducing costs as a result of numerous competitors. The main role for public policy in transportation in Albania is for making decisions related to infrastructure investments. These decisions include both the amount of funding to be delivered from government sources as well as other issues such as zoning and density decisions and protection of rightof-way for future rail and road corridors. In this sense, the role of Albanian government is forward looking. It must envision a likely and socially acceptable future and plan for the according infrastructure investments in our country. Major investments should focus on the maintenance of the existing network, through the modernization and rehabilitation of existing lines, building new roads, repairing or replacing track, tunnels, electrification of networks, security control, system of access to energy and infrastructure, communications, computing, environmental protection measures.

Government should encourage investment in order to restructure and expand the network in the following areas:

- Total reconstruction of existing network

- Building Pogradec -Qafe-Thana line, in order to be connected to Macedonia

- Construction of Milot - Morine line, in order to be connected to Kosovo

- Building Han -Hoti Saranda line

- Construction of a rail line to Rinas Airport

\section{Discussion}

Rail is a sector where today's policy decisions will seriously affect the future of Albania. There is a need for policy action to overcome current network constraints and realize the true value of rail to the Albanian economy. Bold policy decisions 
towards public transport, should be considered. For this reason, policy-makers should focus on the fact than how good can accommodate the future of transport in economic growth. Investments in railways should be made through publicprivate funds. Government should be involved mostly in metropolitan railway. Linking residential areas with the infrastructure should be a priority for public policy. On the other side, private operators should be encouraged to develop other areas, mainly freight transport, industry development. Government should focus on addressing of existing deficiencies in high costs of road transport, to make proper investments. Failure to act will tie Albania further in to road based transport and would not allow the realization of increasing returns to scale, environmental, productivity and social gains that could be seen if rail networks were encouraged to grow.

During the latest 22 years there has been a huge demographic movement in Albania. The people of rural regions moved to big and industrial cities. Thus, the population of the cities grows numerously. As a result, the transport ways of communication became more and more necessary. For policy decision makers, thought must be put towards how rail infrastructure will be integrated into a transportation system. The transport system must be both able to cope with demographic movement. An effective solution to develop the railway is to separate the government from running the railway, (management and operations). Actually all the operations as policy making, investments, management of tools, human resources are under the Ministry of Transport.

\section{Concluding remarks}

Some recommendations deriving from this research are:

- Building of a new railway network in Albania needs a project studied in detail according to EU standards

- Providing a law for railways in Albania according to EU standards

- Ensure managerial independence of the infrastructure manager

- Improve corporate governance in state rail company

- Strengthening licensing bodies as foreseen in the EU Rail Directives

- Organize the railway around costumer needs, instead of territorial structures or railway branches

- Avoiding creating new companies which do not face market demands. In Albania there is already a unsuccessful railway company

- The railway network would make possible good progress of economy and social. It would make possible a connection between Albania, Macedonia, Montenegro, Serbia and over wide in Europe

- The Albanian government must continue the reform process of railways where the deregulation is the most important point except for the aspects (operational, financial and institutional reforms)

- Railway in Albania should be orientated to development policies based on European market standards and rules, quality transport services according to market expectations

- Albanian Government should hire a set of case studies and references to other relevant documents on European railways, which are successful

- There is a need of international donors to support the development and restructuring of Albania Railway (to attract big companies to invest in Albania)

- Attracting of foreign investments for concessions

- Improvement of the legal framework for liberalization of rail market in order to increase the quality of rail freight transportation in Albania

- The privatization of railway should be performed through transparent competition according to the concession law, recently approved by Albanian Parliament

- Increase of management autonomy

- Reduction of staff (HSH has the biggest staff in Europe and this is unnecessary)

- Crucial organizational restructuring

- The urgent reduction of operational costs and state subsidy

- Integration of Albanian railway in the Balkan railway network, the line between Macedonia and Albania (210 $\mathrm{km})$, the modernization of rail lines of VIII Corridor and Nord-South as well

\section{References}

Albanian Transport Policy and Core Network (2007) Ministry of Public Works and Transportation

ALBINVEST (2008) Albanian Infrastructure Today 
Berger. L, S.A (2005) Albania National Transport Plan-Phase 2 Study Draft Final Report, 29-31, 47, 50

Bramo. F (2012) Railway Albania-Kosovo, a way for economic development between two countries, Konferenca e Njëmbëdhjetë Ndërkombëtare Biznesi dhe Punësimi me tematikë "Perspektiva e ekonomisë dhe e biznesit të Kosovës dhe vendeve tjera botërore në shekullin XXI" pages 541-553

Business Plan HSH, Development of service 2010-2016

Business plan of HSH in Albania (2007) The infrastructure

Chouchorelou. D (2009) The human Factor in the Freight Transport System-Management of Change

Deloitte Acces Economics (2011) The true value of railway. The Australiasian Railway Association

EBRD (2006), Albania Strategy Overview

Eurailpress, Competition in Europe's rail freight market

European Railway Deregulation (2009) Essays on efficiency and productivity of European railways

Gómez-Ibáñez.J.A (2004). Railroad Reform:An Overview of the Options. Paper to be presented at the Conference on Railway Reform Rafael del Pino Foundation Madrid September 18-19, 2004

H.SH, Railway Transport Reality and Development Strategy

Hilmola Pekka, O, (2008), Railway Wagon Market Analysis and New Multi-Purpose Wagon Solution for Freight Transports - Finnish Manufacturing Perspective

Hilmola.O-P, Szekely.B (2006) Deregulation of Railroads and Future Development Scenarios in Europe-Literature Analyses of Privatization Process taken place in US, UK and Sweden, Finland

http://trade.ec.europa.eu/doclib/docs/2006/september/tradoc_113342.pdf

http://www.iadb.org/intal/intalcdi/PE/2009/02948.pdf

International Transport Forum (2008) Charges for the use of Rail Infrastructure

Kehoe. $O$ (2003) Economics of Truck and Rail Freight Transportation/ A look at public and external costs and the truck-rail model split

Laisi, M (2009), Market Entry Strategies and confronted barriers on Liberalized Railway Freight Markets in Sweden and Poland, pages $15-18$

Laisi, M (2010), Business Environment and Future Opportunities in Russian Railway Freight Market

Laisi. M (2009) Market Entry Strategies and Confronted Barriers on Liberalized Railway Freight Markets in Sweden and Poland, pages $20,24,26,28,39,40-43,52-55$

Laisi.M (2009), Market Entry Strategies and Confronted Barriers on Liberalized railway Freight Market in Sweden and Poland, Finland

Laisi.M (2010) Business Environment and Future Opportunities in Russian railway Freight Market, Finland

Makitalo. M (2007) Market Entry and the Change In Rail Transport Market When Domestic Freight Transport Opens to Competition in Finland. Finland

Ministry of Public Works and Transportation (2007) Strategy of Transportation Development

Ministry of Transport and Public Works 2007-2013 (2007) Sectorial Strategy of Transport, pages 15, 25, 38, 45

Monslave. C (2011) Railway Reform in South East Europe and Turkey: On the Right Track?, pages 128-136

Saranen.J (2009) Enhancing the Efficiency of Freight Transport by Using Simulation, Finland

Simola. M, Szekely. B (2009) The liberalization process in Europe: Market entry barriers versus competition stimulation-cases of Germany and Hungary, 12, 14, 15, 23, 28-29

Stability Pact Watch Group (2004)

Szekely.B. Progess of Liberalization Process of the Railways in Germany and France, Finland

World Bank (2008) Western Balkans Integration and EU 